\title{
Real-Time Virtual Teaching: Lessons Learned From a Case Study in a Rural School
}

\author{
Michael K. Barbour \\ Sacred Heart University
}

\begin{abstract}
Due to the challenges facing rural schools, many jurisdictions have resorted to the use of virtual school programs to provide curricular opportunities to their students. While the number of virtual schools that rely on synchronous instruction as a primary or significant method of delivery is quite small, there are some programs that do (and a growing number of virtual schools that use it with small groups or individuals). This case study examined the use of synchronous online instruction by one virtual school with students in a single rural school in Newfoundland and Labrador. The data from a variety of collection methods revealed three themes: similarities with online student experiences and their traditional classroom experiences, the development of local learning communities, and the preference for students to use chat over audio.
\end{abstract}

\section{Introduction}

In 1978, Cosby and McDermott indicated that there was a perception that those living in rural areas represented "a small and insignificant segment of the population" of the United States (p. 6). The authors speculated that this was due to urban dominance in matters of politics and commerce, along with a general shift in the population from rural to urban areas. These observations are still relevant 37 years later and are applicable not only to an American context, but in most rural jurisdictions throughout the world. They are particularly true of the Canadian Province of Newfoundland and Labrador, which is located on the east coast of Canada. The province, which has both island and mainland portions, has a total area of approximately 252,000 square miles and a population of a little less than 510,000 people at the time of this study. Although about half of the population resides within a 90-minute drive of the provincial capital, the remainder of the province is sparsely populated. In fact, at the time of this study, 192 of the 294 schools were located in these rural areas (Government of Newfoundland and Labrador, 
2005), 85 of which were deemed "necessarily existent" (i.e., a school that cannot be closed because it is located so far from another school that busing is not feasible).

Based upon the recommendations of government reports (e.g., Crocker, 1989; Crocker \& Riggs, 1979; House, 1986; Riggs, 1987), the province implemented a program of distance education for rural high school students in 1988. The main purpose of the program was to provide secondary level students with courses that were important for postsecondary admission but were difficult to offer in rural schools due to low levels of student enrollment. Following a ministerial panel (Sparkes \& Williams, 2000), the government created the Centre for Distance Learning and Innovation (CDLI) to be founded upon the web-based, distance education model.

The purpose of this study was to explore how virtual schooling was being implemented in a Newfoundland and Labrador rural schools, specifically with regard to synchronous online instruction. I begin with a discussion of the literature related to K-12 online teaching, specifically research related to synchronous instruction. This is followed by a description of the case study methodology that was used to collect data at this rural school in Newfoundland and Labrador, including a detailed description of the synchronous model of instruction utilized by the virtual school (i.e., the CDLI). Next, I outline and discuss three themes that emerged in the data. Finally, I provide implications for practice and suggestions for future research.

\section{Literature Review}

There is a growing body of literature related to teaching in the K-12 online learning environment (Davis \& Roblyer, 2005; DiPietro, 2010; DiPietro, Ferdig, Black, \& Preston, 2008; Easton, 2003; Harms, Niederhauser, Davis, Roblyer, \& Gilbert, 2006; Lowes, 2005; Morris, 2002; Rice, 2011; Roblyer \& McKenzie, 2000; Smith, 2009). There are even untested national standards related to online teaching that have been adopted by several states (Barbour, Clark, DeBruler, \& Bruno, 2014; International Association for K-12 Online Learning, 2011; North American Council for Online Learning, 2007). The vast majority of online instruction that occurs within the K-12 online learning environment is asynchronous in nature (Barbour, 2013; Barbour \& Adelstein, 2013). In fact, there are only two K-12 online learning programs in North America that have been known to utilize a strong synchronous instructional model: the CDLI in Newfoundland and Labrador (see Barbour, 2007b) and, formerly, ACCESS Distance Learning in Alabama (see Roblyer, Freeman, Stabler, \& Schniedmiller, 2007).

As the majority of K-12 online learning programs use a primarily asynchronous instructional model, there isn't as much known about synchronous instruction within virtual schooling. For example, Murphy and Coffin (2003) described the affordances and constraints of synchronous tools used by the CDLI as a part of its French as a second language courses from the perspective of student-to-teacher, student-to-student, and student-to-content interaction. Further, Murphy (2009) found that synchronous tools were useful in promoting speaking in blended, elementary level French as a second language courses, but that poor audio quality, the time lag, and students' preference for the chat feature were challenges that teachers faced. Additionally, Nippard and Murphy (2007) investigated how social presence was manifested in the CDLI's synchronous environment and found that teachers exhibited social presence through use of the audio feature in the virtual classroom environment, while students relied primarily on the text-based chat feature.

In their study of transactional distance with CDLI teachers, Murphy and Rodríguez-Manzanares (2008) found that to decrease the students' sense of transactional distance teachers needed to build rapport and community with their students. But they also found that the curriculum and teacher-centered tools (such as the learning management system) placed limitations on online teachers and that teachers needed to leverage their real-time interaction and engagement with students. Transactional distance is a 
psychology or sense of distance experienced by the student in an online environment, and researchers have found that to decrease transactional distance, highly autonomous learners in an environment with a high level of dialogue and a low level of structure are needed (Moore, 1972, 1973, 1983, 1993; Moore \& Kearsley, 1996). Further, Murphy and Rodríguez-Manzanares (2009a) reported that the nature of both synchronous and asynchronous tools forced online teachers with the CDLI to transition their practice to "more learner-centered, facilitative forms of teaching" (p. 14). This perception was also reported in a panCanadian study of online teachers from a variety of K-12 online learning programs (Murphy \& Rodríguez-Manzanares, 2009b). Conversely, Murphy, Rodríguez-Manzanares, and Barbour (2011) found that online teachers in the synchronous environment actually relied more on teacher-focused rather than student-centered approaches. One of the reasons for this contradiction may be the difficulties that online teachers reported in developing rapport with the students - even using the synchronous tools that were available to them (Murphy \& Rodríguez-Manzanares, 2012). Beyond the research into the CDLI and other Canadian jurisdictions, there has been little research into synchronous K-12 online teaching within North America.

Outside of the North American context, there are several jurisdictions that utilize synchronous instruction as a primary or significant component of their online teaching model (Barbour, 2014; Barbour, Brown et al., 2011; Barbour, Hasler Waters, \& Hunt, 2011). For example, the various e-learning clusters of the Virtual Learning Network in New Zealand utilize a model in which most of the instruction is delivered to students using a synchronous video-conferencing system for one hour each week (Barbour \& Bennett, 2013; Bennett \& Barbour, 2012; Lai \& Pratt, 2009; Pullar \& Brennan, 2008; Roberts, 2009). However, beyond general descriptions, there has also been a lack of international research into the synchronous instructional model in the K-12 online teaching environment.

\section{Methodology}

The purpose of this study was to explore virtual schooling in a Newfoundland and Labrador rural school. Specifically, this study examined the following research question:

- What are the students' experiences during their synchronous time online?

As the research question was designed to understand students' experiences in a virtual high school by examining how those experiences operated at a particular rural school, a case study was the most appropriate methodology. Merriam (1998) indicates that a case study is designed to provide "an intensive, holistic description and analysis" of a specific phenomenon (p. 27). This is supported by Shank (2002), who describes the main purpose of a case study as providing an understanding of a unique case.

According to Merriam (1998), "Any and all methods of gathering data, from testing to interviewing, can be used in a case study, although certain techniques are used more than others” (p. 28). Those techniques usually include interviews, document analysis, and participant observation (Bassey, 1999; Merriam, 1998; Stake, 1995; Yin, 2003). Further, the use of multiple sources of data from multiple data-collection methods allows researchers to triangulate themes that may emerge from the data (Patton, 2002). The data collection for this study occurred over a 6-month period and began with a semistructured focus group, followed by monthly interviews for 5 months, and observations of students during their scheduled synchronous and asynchronous classes.

The data were analyzed using an inductive analysis approach, specifically the constant comparative method, which involves scanning the data for categories and relationships within individual transcripts and between transcripts (LeCompte \& Preissle, 1993). As Ezzy (2002) described, the process of constant comparison consists of developing and identifying codes that can then be compared across the data. In particular, I used Ruona's (2005) four-stage process for the table format and the find and replace 
feature of Microsoft Word to conduct a more systematic analysis of qualitative data. The four stages include preparing the data, familiarization of the data, coding the data, and generating meaning from the data (for a complete description of the methodology, see Barbour [2007a] and Barbour and Hill [2011]).

\section{The Case}

Beaches All Grade has approximately 100 students and a staff of 15 teachers. The students at Beaches All Grade came from three different communities: Beaches itself, Cape Random (approximately 7 miles south), and Clarke’s Bay (approximately 7 miles north). During the 2005-2006 school year, there were 12 students enrolled in eight different CDLI courses (see Barbour [2007b] for a detailed description of the province of Newfoundland and Labrador, the challenges it has faced in providing educational opportunities in rural areas, and the history of distance education as a means to address that challengeincluding the CDLI and the nature of its online learning experience).

Just as if you were to observe 10 classroom teachers teach a single lesson or a single teacher teach 10 lessons, you would see a wide variety of instructional approaches. This variety of the instructional practices of e-teachers during their synchronous lessons was apparent during the study. In addition, this synchronous component was also where most of the instruction actually occurred, as most of the asynchronous "instruction" was similar to an independent learning environment rather than actual instruction (Greenway \& Vanourek, 2006).

Many e-teachers used the virtual classroom in much the same way that they would use a traditional classroom. For example, it was common for teachers to use the electronic whiteboard in a manner similar to how they would use a traditional whiteboard as a space to diagram new concepts as they were introduced to students (see Figure 1).

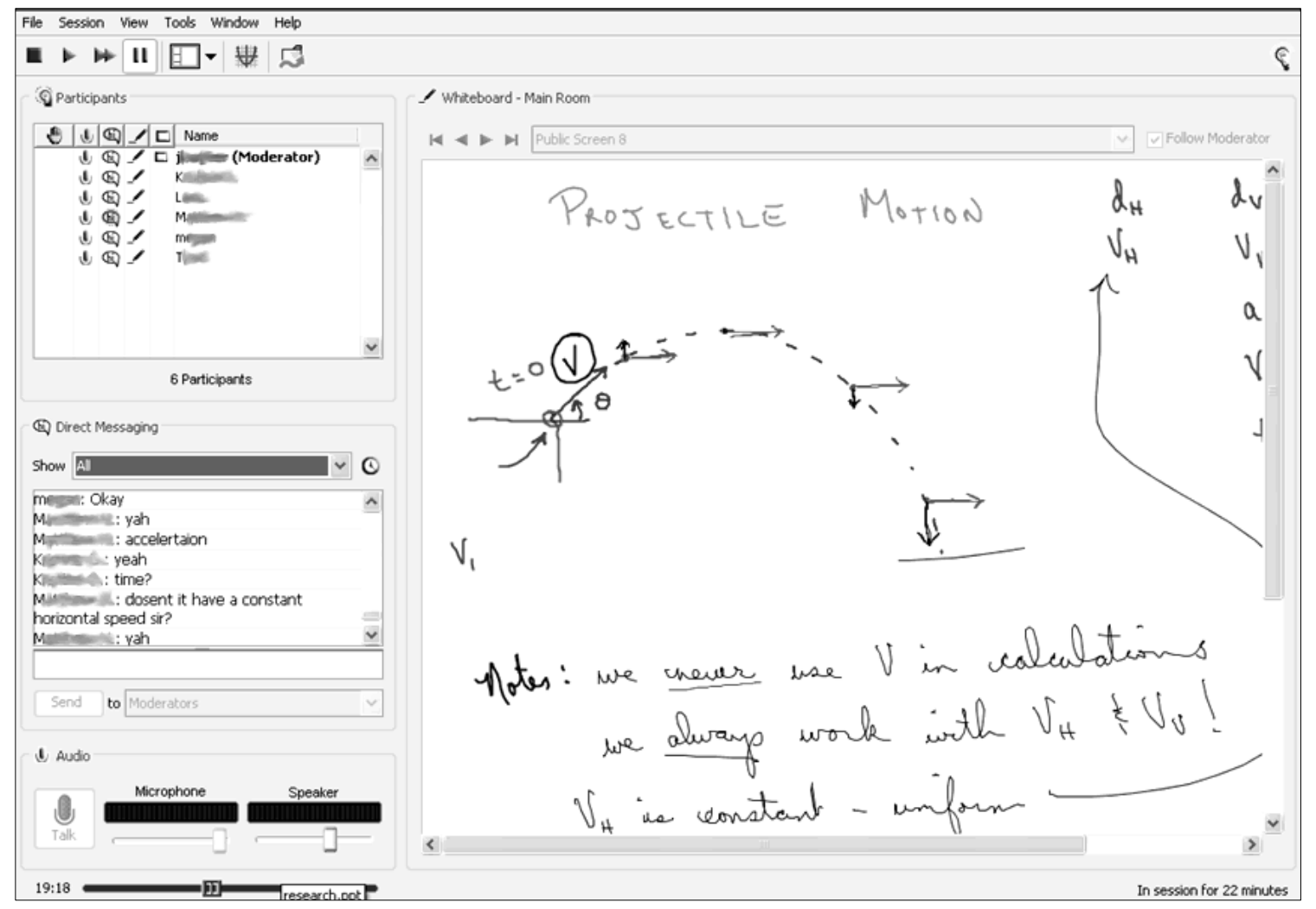

Figure 1. Example of a teacher introducing a new concept on the electronic whiteboard using Elluminate Live! 
In this example, notice that the students used the direct messaging area to ask the e-teacher questions, and he addressed these questions as he introduced the concept. Unlike some virtual classrooms, the synchronous tool utilized by the CDLI allowed for only one individual to control the microphone at any given time. Because of this, e-teachers encouraged students to use the text-based chat or direct messaging (pictured near the bottom left in the screenshots), as it allowed students to interact with the eteacher without the e-teacher having to release the microphone. It also allowed the e-teacher to address the students' questions while simultaneously conversing with the class.

It was also common for e-teachers, particularly in mathematics and the sciences, to use the whiteboard as a space to work out sample problems for the teachers (see Figure 2).

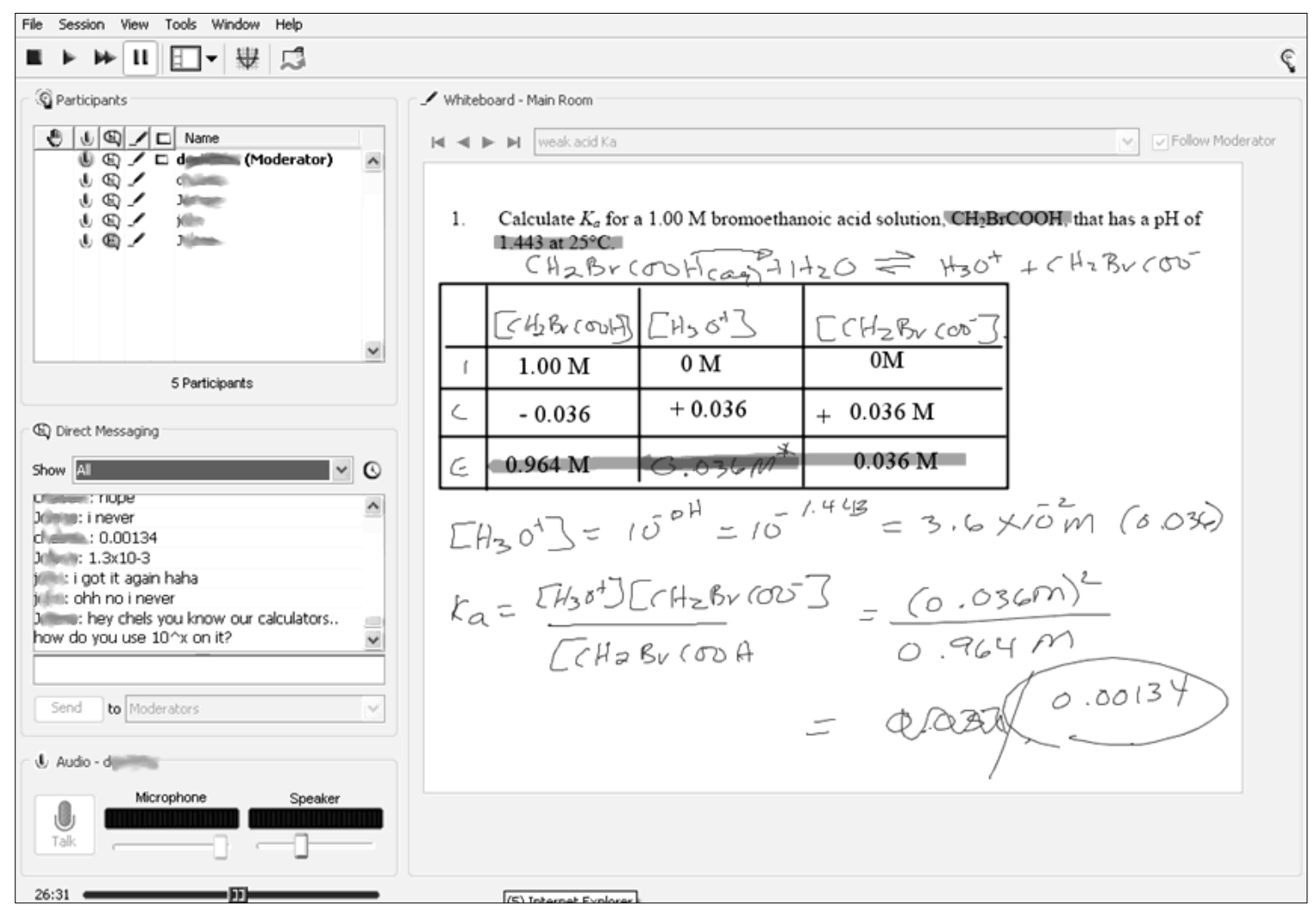

Figure 2. Example of a teacher working out sample problems using Elluminate Live!

Notice that in this example, the e-teacher asked the students to complete the calculations on their own and post them in the direct messaging area, prior to her writing the correct answer on the whiteboard. This was another way in which e-teachers encouraged interaction through the use of direct messaging.

Still other e-teachers used the whiteboard as a tool to deliver lectures, using it as a space to present notes and images-usually created using Microsoft PowerPoint (see Figure 3, next page). In this example, the e-teacher has turned off the public display of the direct messaging. This meant that students still had access to the direct messaging, but only the e-teacher was able to see what they wrote. This way the students were still able to ask the e-teacher questions or to let him know if they did not understand something, but they were not able to communicate with each other. It was in this synchronous environment within the CDLI that the current study occurred. 


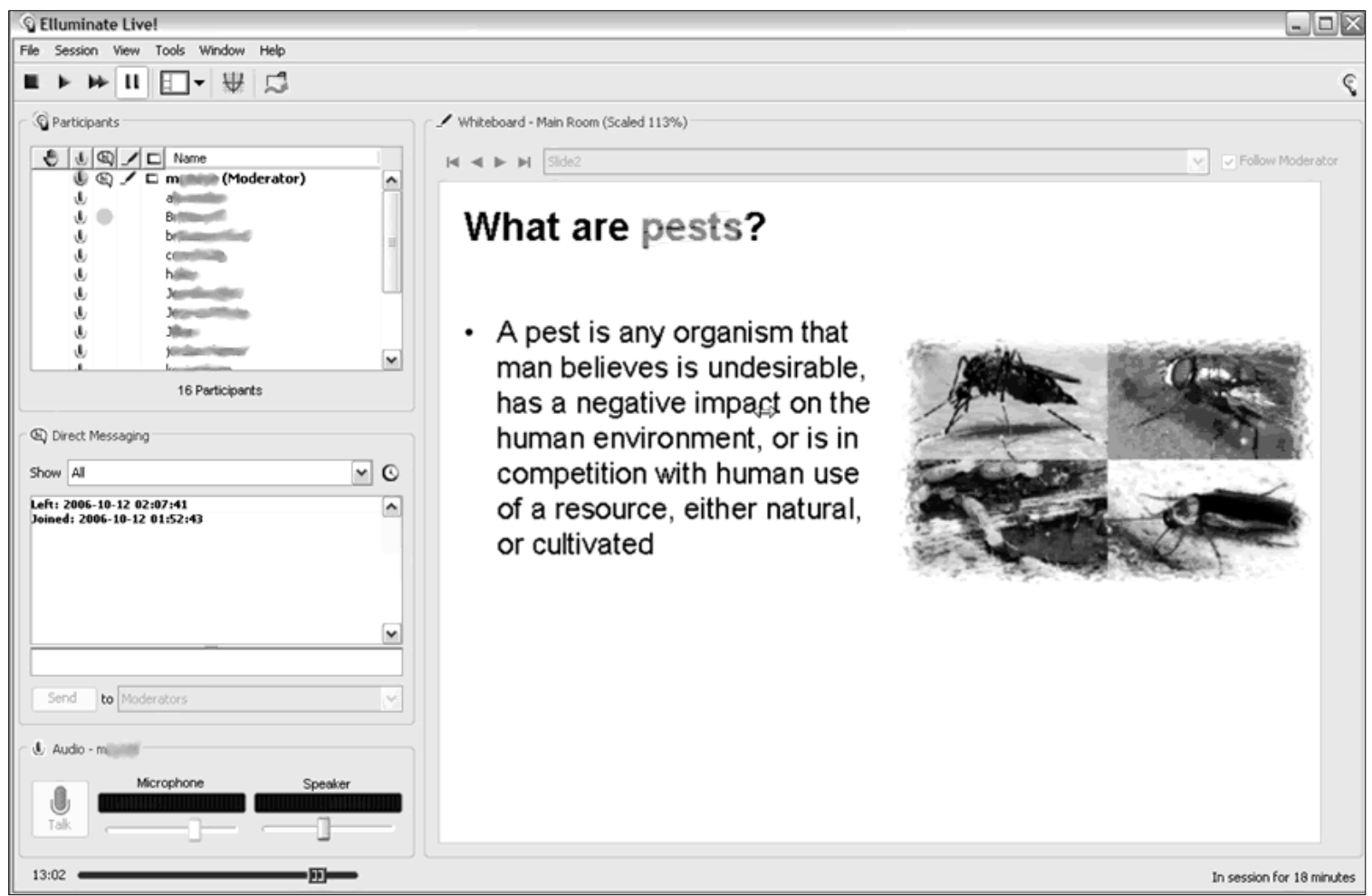

Figure 3. Example of a teacher lecturing with presentation slides using Elluminate Live!

\section{Results and Discussion}

The data revealed three main themes. First, the student experiences in the synchronous online learning environment were quite consistent with what one would expect of student experiences in a realtime face-to-face classroom. Second, a strong sense of community and a local online-learning support group developed among the students sitting in the room as they engaged in their synchronous online classes. Third, during their synchronous online classes, the students preferred to interact using the direct message or chat features, as opposed to the audio functions.

\section{Students’ Synchronous Experiences}

In addition to the similarities found between what we might expect a classroom teacher to do in a traditional classroom environment and what the e-teachers did in the virtual classroom, there were also many similarities between how we would expect students to describe their experience in a traditional classroom and how students described their experiences during their synchronous class time. For example, one student described "just sitting there and listening to the teacher" (JD—n.b., all names are pseudonyms). While not evincing a very active form of participation, JD's quote at least indicated that the student was "listening." Fortunately for the e-teachers, not all of the students described their synchronous experience in such passive terms. JD even described in a later interview a more active participation: "If he [the teacher] says something important, I just flip back up to the screen and see what he is writing up and then write up what he's writing up or print [sic] it off." However, even in this context, the important materials get translated into a physical artifact (as opposed to the electronic environment offered by the virtual classroom). 
In fact all of the students described an active participation during their synchronous classes. In her language arts class, Mya described one of her synchronous classes:

I'd have Elluminate Live! up and the instruction, the instructor would be giving like the lesson that we would be reviewing that day. Normally, its just going over a part in a novel or something like that, and then we have to evaluate it and take roles in it. ... We would type them all first, and then we would copy and paste them into the direct messaging.

These descriptions are consistent with the kinds of descriptions that might be expected in a traditional classroom: students taking notes based upon their science teacher's lecture; students reading a novel aloud in an English class and then answering questions on the passage they had just completed; fine arts students searching through provided resources to find examples of a particular artistic concept; or a mathematics teacher beginning the class by reviewing the formula and sample problems from the previous class.

One of the reasons that e-teachers and their students make effective use of their synchronous time may be these similarities to the traditional classroom environment. In his discussion of how innovations are diffused, Rogers (2003) described five perceived attributes that potential adopters base their opinions of an innovation on: relative advantage, compatibility, complexity, trialability, and observability. According to Surrey and Ely (2007), a person is more likely to use something new if it "offers them a better way to do something; is compatible with their values, beliefs and needs; is not too complex; can be tried out before adoption; and has observable benefits" (p. 106). The virtual classroom utilized by the CDLI allows teachers to teach in a way that is compatible with how they have taught in the traditional classroom environment.

One aspect of the virtual classroom that is different than a traditional classroom that e-teachers seem to have adopted was alluded to by Peter when he said, "He [the teacher] would like put multiple choices on the board, ah, up on the whiteboard and we'd have to select which answer." The use of the polling feature to ensure that students were paying attention was seen as "a better way to do" this in a virtual environment where the e-teacher was unable to see their students. This fact was not lost on the students either. Jasmine described this instructional strategy as follows: "My teacher usually gets us to say something or put up a checkmark to make sure we are paying attention.”

Students were much more productive during their synchronous class time compared to their asynchronous class time, as Max indicated there was no actual teacher there to police the students and keep them on task. Even the use of the polling feature was not always effective, as was discovered during an observation of the students during a synchronous language arts class. From the beginning to the end of class, the three students talked about the school's graduation, the upcoming trip to Signal City, what had occurred the previous weekend, what they were going to do that coming weekend, their plans for summer break, the movie The Breakfast Club, school spirit, and so on. During these conversations, all three students were logged into Elluminate Live!, and one of the three students appeared to be responsible for paying closer attention, as she would periodically tell the other two to type something or click on something.

While this particular class was a rarity, at least based upon observations, the students' behavior is an illustration of the difficulties of the virtual environment for students who are being "compelled to assume a degree of autonomy they are not ready to handle" (Moore, 1973, p. 84). There were other examples of off-task behavior. For example, there was a greater amount of conversation between the students in the distance education room than a classroom teacher would be accustomed to seeing. This is not to suggest that the students were talking to each other on a continuous basis. On the contrary, based on observations of 22 synchronous classes, the amount of conversation between students was usually 
limited to 10-15 minutes out of a 60-minute class and, as indicated in the table below, much of that conversation was focused on the content of the synchronous class.

Table 2 Percentage of the conversation during synchronous classes about the subject area with fellow students in the local distance education room

\begin{tabular}{|l|l|l|l|l|l|}
\hline Student & Interview 1 & Interview 2 & Interview 3 & Interview 4 & Mean \\
\hline Cassandra & $50 \%$ & $30 \%-40 \%$ & $25 \%$ & $20 \%-25 \%$ & $35 \%$ \\
\hline JD & $50 \%$ & $40 \%$ & $75 \%-80 \%$ & $40 \%-60 \%$ & $55 \%$ \\
\hline Peter & $40 \%$ & $80 \%$ & NA & $50 \%$ & $55 \%$ \\
\hline Mya & $75 \%$ & $100 \%$ & $100 \%$ & $75 \%$ & $90 \%$ \\
\hline Kasmine & $95 \%$ & $100 \%$ & $100 \%$ & $100 \%$ & $100 \%$ \\
\hline Justine & $95 \%$ & $90 \%$ & $90 \%$ & $50 \%$ & $80 \%$ \\
\hline Max & $90 \%$ & $65 \%$ & $25 \%$ (math) & $10 \%$ & $40 \%$ \\
\hline Mean & $70 \%$ & $50 \%$ & $50 \%$ (science) & & $70 \%$ \\
\hline
\end{tabular}

If you remove the two students who were enrolled in classes by themselves from the table above (as these students did not have fellow students to talk to in the local distance education room while they were engaged in this virtual schooling), the overall mean for conversation with other students in the room about the subject area drops to approximately 55\%. So even though the synchronous time was the time when students were most on task, there were still times when they were engaged in other, distracting activities.

The students' decision about whether to pay attention or talk about other things during their synchronous class time was based upon a number of different factors. The difficulty or importance of the course or the particular topic the e-teacher was covering was mentioned by Max: "We'll talk every now and then, but if he's [the e-teacher] talking about something important, we'll pay attention.” This behavior is consistent with the differences between adult and adolescent learners described by Knowles (1970). The CDLI students were not as self-directed as adult learners; had not accumulated a variety of personal strategies and resources for their learning; were still oriented to learning due to a requirement, as opposed to a specific goal-related desire; and still possessed an orientation toward learning that was focused upon the subject, as opposed to a particular problem.

\section{Local Synchronous Learning Community}

As described earlier in this section, the students spent between 10-15 minutes per class (or 15\% to $25 \%$ of the class time) talking to one another, and approximately $65 \%$ of that conversation was about the content being presented in that class. Max described these conversations as follows: 
It might be something about what's going on in class, if you got, well, if we don't understand what, cause usually one of us understands what's going on, we'll just talk about that for a second.... Just like say where'd he get that answer to and whatever, and the other person say yeah.

Kathy and Justine both described these conversations in a much briefer fashion. Kathy said she would talk to other students "sometimes if I have to ask them a question about stuff.” And Justine said, "If we don’t understand something we ask each other."

It was not surprising that these students built a support community among themselves that they utilized during their synchronous classes. A stronger sense of community is normally present in rural schools (Kannapel \& DeYoung, 1999), and students at Beaches used terms like "friendly," "close knit," and "family" to describe their rural school. However, the further decrease from their regular small class size at Beaches All Grade to an even smaller local virtual school class size increased the sense of community for these students.

These students all felt that the smaller class size in their virtual school classes created a greater sense of community with their local virtual school classmates. Conrad (2002) described place-based communities, or communities that were physically together, as "like-minded groups of people [gathered] together in the spirit of shared goals" (p. 4). In the case of CDLI, the shared goals focused on understanding the material that their e-teacher presented. Cross (1998) believed that a learning community was intended to foster "active learning over passive learning, cooperation over competition, and community over isolation” (p. 5). CDLI students were quite active in their learning and cooperated to ensure that everyone who expressed confusion understood the material; students frequently asked each other content-based questions during synchronous class time.

\section{Interaction-Text Over Talk}

As illustrated earlier, the two main methods that students had for interacting with their teacher and the other students in the virtual classroom were the microphone or direct messaging. While students did use both media, all but one student preferred to use direct messaging when given the choice. This behavior was consistent with Nippard (2005), who found that CDLI students in the six courses that he observed preferred to use direct messaging in their virtual classrooms. Most of the students who preferred direct messaging did so because they were shy about speaking over the microphone in general or because they felt that they didn't know the online classmates. "I just don't like talking over the mic," said Jasmine, and Justine indicated, "I guess I'm kind of shy using the mic." Mya was a little more practical about her discomfort with speaking out over the microphone: "I'm not comfortable with it personally.... I just find it quicker and easier, you get more people talking at once rather than one at a time.”

This pattern is similar to events in a traditional classroom-some students don't mind speaking up, but just as many or more prefer to not speak. Another possible explanation, however, may lie in the sense of community that existed between the students at Beaches and their virtual school classmates. Unlike the tight local community that had developed, there was little sense of community within the virtual environment. "I don't even know most of them, don't know what they look like, only know their names," indicated Peter. This was fairly consistent with comments made by all but one of the eight students. Mya was the only student that relayed any sense of familiarity with her online classmates.

While the lack of familiarity with their online colleagues did decrease the amount of verbal interaction and increase the amount of written interaction that seven of the eight students had, it didn't decrease the overall amount of their interaction. The exception to this was Max, who stated, "I probably won't make certain comments because I don't know how certain people would react, so I just keep my 
mouth shut." Given this quote, one might speculate that these comments would not necessarily be related to the class content and that Max's level of on-task interaction was not affected by the lack of familiarity with his virtual school classmates.

A sense of community or a connection between learners is affected by, among other things, the level of social presence felt by the learners (Gunawardena \& Zittle, 1997; Rovai, 2001). Short, Williams, and Christie (1976) defined social presence as "the degree of awareness of another person in an interaction and the consequent appreciation of an interpersonal relationship" (p. 66), while Garrison and Anderson (2003) defined it as "the ability of learners to project themselves socially and emotionally into a community of inquiry through the mediums of communication being used” (p. 49). The students reported two e-teachers had students send in pictures and information about themselves, which the e-teacher used during a synchronous class to introduce the students to each other. However, the CDLI students at Beaches still did not feel that their online classmates projected themselves in any way that fostered any meaningful relationship.

The two variables that make up social presence are intimacy and immediacy (Short et al., 1976). $\mathrm{Tu}$ (2002) stated that intimacy included things such as "eye contact, physical proximity, and topic of conversation" (p. 133), while immediacy was "the psychology distance between a communicator and the recipient of the communication” (p. 134). The tools included in the virtual classroom, along with the students' use of emoticons and other linguistic features associated with text messaging, allowed the students to exhibit some level of intimacy; however, the CDLI students at Beaches felt a high degree of distance from their online classmates, which accounted for the perceptions of a low level of social presence and lack of community with their online classmates.

\section{Conclusions and Implications}

Rural schooling faces many challenges. Distance education programs, such as virtual schools, are often designed to provide rural students with courses that are difficult to offer due to low levels of student enrollment and lack of specialized teachers. The purpose of this study was to explore the implementation of one virtual school program in a Newfoundland and Labrador rural school, specifically their synchronous online instruction. The students' experiences in this synchronous environment were consistent with the experience that these students would have likely received in a more traditional face-toface classroom. Further, a strong sense of community support developed among the local students enrolled in the virtual school program during their synchronous sessions. Finally, during their synchronous classes the students preferred to interact using chat as opposed to using the microphone and speaking to the group.

As an isolated case study, this study represents a limited attempt to address the lack of research into synchronous online teaching in the virtual school environment. While synchronous learning represents a small amount of the actual online instruction that occurs within virtual schools, there are several programs that utilize small-group and individualized synchronous instruction. As such, lessons learned in this environment may be useful to other virtual school programs - just in slightly different contexts and modes of usage. These lessons include the need for online teachers to be better trained to utilize the synchronous tools beyond what they have been conditioned to do in the face-to-face environment. Additionally, both online teachers and individual schools participating in virtual school programs need to find ways to foster students' support of each other during their synchronous classes. Finally, online teachers need to find ways to help foster an online sense of community within their synchronous sessions that might encourage students to be more active and, in particular, vocal in their participation. 
All of that said, given that this study was a case study of a small number of students in a single rural school, further research is needed into promising practices for synchronous online instruction with K-12 learners. Given the lack of research into synchronous instruction in the virtual schooling environment overall, a call for additional research of any kind that focuses on synchronous instruction would be warranted. However, based on this specific case study, it would be interesting to explore whether these findings would still be relevant today. The data for this particular case was collected almost a decade ago, and advances in virtual classroom environments, video technology, and the availability of bandwidth might yield different results today. Finally, it would also be interesting to examine whether this additional time had any impact on the specific synchronous instructional practices of teachers using these tools (i.e., are e-teachers still replicating traditional classroom pedagogy), which might also impact both how the students experience their synchronous instruction and-in particular-the time on task during that instruction.

\section{References}

Barbour, M. K. (2007a). What are they doing and how are they doing it? Rural student experiences in virtual schooling (Unpublished doctoral dissertation). University of Georgia, Athens, GA.

Barbour, M. K. (2007b). Portrait of rural virtual schooling. Canadian Journal of Educational Administration and Policy, (59). Retrieved from http://www.umanitoba.ca/publications/cjeap/articles/barbour.html

Barbour, M. K. (2013). The landscape of K-12 online learning: Examining what is known. In M. G. Moore (Ed.), Handbook of distance education (3rd ed., pp. 574-593). New York: Routledge.

Barbour, M. K. (2014). A history of international K-12 online and blended instruction. In R. Ferdig \& K. Kennedy (Eds.), Handbook of research on K-12 online and blended learning (pp. 25-50). Pittsburgh, PA: Entertainment Technology Center Press, Carnegie Mellon University. Retrieved from http://press.etc.cmu.edu/files/Handbook-Blended-Learning Ferdig-Kennedy-etal web.pdf

Barbour, M. K., \& Adelstein, D. (2013). Voracious appetite of online teaching: Examining labour issues related to K-12 online learning. Vancouver, BC: British Columbia Teachers Federation. Retrieved from http://www.bctf.ca/uploadedFiles/Public/Issues/Technology/VoraciousAppetite.pdf

Barbour, M. K., \& Bennett, C. (2013). The FarNet journey: Effective teaching strategies for engaging Māori students on the Virtual Learning Network. Journal of Open, Flexible and Distance Learning, 17(1), 12-23. Retrieved from http://journals.akoaotearoa.ac.nz/index.php/JOFDL/article/viewFile/195/156

Barbour, M. K., Brown, R., Hasler Waters, L., Hoey, R., Hunt, J., Kennedy, K., Ounsworth, C., Powell, A., \& Trimm, T. (2011). Online and blended learning: A survey of policy and practice from K-12 schools around the world. Vienna, VA: International Association for K-12 Online Learning.

Barbour, M. K., Clark, T., DeBruler, K., \& Bruno, J. A. (2014). Evaluation and approval constructs for online and blended courses and providers. Lansing, MI: Michigan Virtual Learning Research Institute at MVU. Retrieved from http://media.mivu.org/institute/pdf/eval_constructs.pdf

Barbour, M. K., Hasler Waters, L., \& Hunt, J. (2011) Online and blended learning: Case studies from K12 schools around the world. Vienna, VA: International Association for K-12 Online Learning. 
Barbour, M. K., \& Hill, J. R. (2011). What are they doing and how are they doing it? Rural student experiences in virtual schooling. Journal of Distance Education, 25(1). Retrieved from http://www.jofde.ca/index.php/jde/article/view/725

Bassey, M. (1999). Case study research in educational settings. Buckingham, England and Philadelphia: Open University Press.

Bennett, C., \& Barbour, M. K. (2012). The FarNet journey: Perceptions of Māori students engaged in secondary online learning. Journal of Open, Flexible \& Distance Learning, 16(1). Retrieved from http://journals.akoaotearoa.ac.nz/index.php/JOFDL/article/view/105

Conrad, D. (2002). Deep in the hearts of learners: Insights into the nature of online community. Journal of Distance Education, 17(1), 1-19.

Cosby, A. G., \& McDermott, V. P. (1978). Rural youth in context. In A. G. Cosby \& I. Charner (Eds.), Education and work in rural America: The social context of early career decision and achievement (pp. 1-18). College Station, TX: Texas A\&M University.

Crocker, R. (1989). Towards an achieving society. St. John's, NL: Queen’s Printing for Newfoundland and Labrador.

Crocker, R., \& Riggs, F. T. (1979). Improving the quality of education: Challenge and opportunity. St. John's, NL: Queen's Printing for Newfoundland and Labrador.

Cross, K. P. (1998). Why learning communities? Why now? About Campus, 3(3), 4-11.

Davis, N. E., \& Roblyer, M. D. (2005, October). A collaborative project to prepare virtual teachers. Paper presented at the Virtual High School Symposium, Denver, CO.

DiPietro, M. (2010). Virtual school pedagogy: The instructional practices of K-12 Virtual School Teachers. Journal of Educational Computing Research, 42(3), 327-354.

DiPietro, M., Ferdig, R. E., Black, E. W., \& Preston, M. (2008). Best practices in teaching K-12 online: Lessons learned from Michigan Virtual School teachers. Journal of Interactive Online Learning, 7(1). Retrieved from http://www.ncolr.org/jiol/issues/pdf/7.1.2.pdf

Easton, S. (2003). Clarifying the instructor's role in online distance learning. Communication Education, 52(2), 87-105.

Ezzy, D. (2002). Qualitative analysis: Practice and innovation. London: Routledge.

Garrison, D. R., \& Anderson, T. (2003). E-Learning in the 21st century: A framework for research and practice. London: Routledge/Falmer.

Government of Newfoundland and Labrador. (2005). Education statistics: Elementary-secondary. St. John's, NL: Queen's Printing for Newfoundland and Labrador.

Greenway, R., \& Vanourek, G. (2006). The virtual revolution: Understanding online schools. Education Next, (2). Retrieved from http://media.hoover.org/sites/default/files/documents/ednext20062_34.pdf 
Gunawardena, C. N., \& Zittle, F. J. (1997). Social presence as a predictor of satisfaction within a computer-mediated conferencing environment. American Journal of Distance Education, 11(3), $8-26$.

Harms, C. M., Niederhauser, D. S., Davis, N. E., Roblyer, M. D., \& Gilbert, S. B. (2006). Educating educators for virtual schooling: Communicating roles and responsibilities. The Electronic Journal of Communication, 16(1-2). Retrieved from http://public.vrac.iastate.edu/ gilbert/papers/JP2007harms-niederhauser.pdf

House, D. (1986). Education for self-reliance: A report on education and training in Newfoundland. St. John's, NL: Queen's Printing for Newfoundland and Labrador.

International Association for K-12 Online Learning. (2011). National standards for quality online teaching. Vienna, VA: Authors. Retrieved from http://www.inacol.org/wpcontent/uploads/2015/02/national-standards-for-quality-online-courses-v2.pdf

Kannapel, P. J., \& DeYoung, A. J. (1999). The rural school problem in 1999: A review and critique of the literature. Journal of Research in Rural Education, 15(2), 67-79.

Knowles, M. S. (1970). The modern practice of adult education: Andragogy vs. pedagogy. New York, NY: Association Press.

Lai, K.-W., \& Pratt, K. (2009). Technological constraints and implementation barriers of using videoconferencing for virtual teaching in New Zealand secondary schools. Journal of Technology and Teacher Education, 17(4), 505-522.

LeCompte, M. D., \& Preissle, J. (1993). Ethnography and qualitative design in educational research (2nd ed.). San Diego: Academic Press.

Lowes, S. (2005). Online teaching and classroom change: The impact of virtual high school on its teachers and their schools. Naperville, IL: Learning Point Associates.

Merriam, S. B. (1998). Qualitative research and case study applications in education. San Francisco, CA: Jossey-Bass Publishers.

Moore, M. G. (1972). Learner autonomy: The second dimension of independent learning. Convergence, Fall, 76-88.

Moore, M. G. (1973). Toward a theory of independent learning and teaching. Journal of Higher Education, 44(12), 661-679.

Moore, M. G. (1983). The individual adult learner. In M. Tight (Ed.), Education for adults: Volume 1 Adult learning and education (pp. 153-168). London, UK: Croom Helm Ltd.

Moore, M. G. (1993). Theory of transactional distance. In D. Keegan (Ed.), Theoretical principles of distance education (pp. 22-38). London: Routledge.

Moore, M. G., \& Kearsley, G. (1996). Distance education: A systems view. Belmont, CA: Wadsworth.

Morris, S. (2002). Teaching and learning online: A step-by-step guide for designing an online K-12 school program. Lanham, MD: Scarecrow Press Inc. 
Murphy, E. (2009). Online synchronous communication in the second-language classroom. Canadian Journal of Learning and Technology, 35(3). Retrieved from http://www.cjlt.ca/index.php/cjlt/article/view/539

Murphy, E., \& Coffin, G. (2003). Synchronous communication in a web-based senior high school course: Maximizing affordances and minimizing constraints of the tools. American Journal of Distance Education, 17(4), 235-246.

Murphy, E., \& Rodríguez-Manzanares, M. (2008). Revisiting transactional distance theory in a context of web-based high-school distance education. Journal of Distance Education, 22(2), 1-14. Retrieved from http://www.ijede.ca/index.php/jde/article/view/38/550

Murphy, E., \& Rodríguez-Manzanares, M. (2009a). Sage without a stage: A cultural historical activity theory perspective on E-teaching in web-based, high-school classrooms. International Review of Research in Open and Distance Learning, 10(3). Retrieved from http://www.irrodl.org/index.php/irrodl/article/view/579/1300

Murphy, E., \& Rodríguez-Manzanares, M. (2009b). Learner-centredness in high-school distance learning: Teachers' perspectives and research-validated principles. Australasian Journal of Educational Technology, 25(5), 597-610. Retrieved from http://www.ascilite.org.au/ajet/ajet25/murphy.pdf

Murphy, E., \& Rodríguez-Manzanares, M. (2012). Rapport in distance education. International Review of Research in Open and Distance Learning, 13(1), 167-190. Retrieved from http://www.irrodl.org/index.php/irrodl/article/view/1057

Murphy, E., Rodríguez-Manzanares, M., \& Barbour, M. (2011). Asynchronous and synchronous online teaching: Perspectives of Canadian high school distance education teachers. British Journal of Educational Technology, 42(4), 583-591.

Nippard, E. C. (2005). Social presence in the web-based synchronous secondary classroom (Unpublished thesis). Memorial University of Newfoundland, St. John’s, NL.

Nippard, N., \& Murphy, E. (2007). Social presence in the web-based synchronous secondary classroom. Canadian Journal of Learning and Technology, 33(1). Retrieved from http://www.cjlt.ca/index.php/cjlt/article/view/24/22

North American Council for Online Learning. (2007). National standards for quality online teaching. Vienna, VA: Authors.

Patton, M. Q. (2002). Qualitative research and evaluation methods (3rd ed.). Thousand Oaks, CA: Sage Publications.

Pullar, K., \& Brennan, C. (2008). Personalising learning for secondary students working in a blended (distance/face to face/vocational) learning environment. Computers in New Zealand Schools, 20(2), 6-16

Rice, K. (2011). Making the move to K-12 online teaching: Research-based strategies and practices. Boston: Pearson.

Riggs, F. T. (1987). Report of the Small Schools Study Project. St. John’s, NL: Queen’s Printing for Newfoundland and Labrador. 
Roberts, R. (2009). Video conferencing in distance learning: A New Zealand schools' perspective. Journal of Distance Learning, 13(1), 91-107.

Roblyer, M. D., Freeman, J., Stabler, M., \& Schniedmiller, J. (2007). External evaluation of the Alabama ACCESS initiative phase 3 report. Eugene, OR: International Society for Technology in Education.

Roblyer, M. D., \& McKenzie, B. (2000). Distant but not out-of-touch: What makes an effective distance learning instructor? Learning and Leading With Technology, 27(6), 50-53.

Rogers, E. M. (2003). Diffusion of innovations (5th ed.). Free Press: New York, NY.

Rovai, A. P. (2001). Classroom community at a distance: A comparative analysis of two ALN-based university programs. Internet and Higher Education, 4(2), 105-118.

Ruona, W. E. A. (2005). Analyzing qualitative data. In R. A. Swanson \& E. F. Holdton III (Eds.), Research in organizations: Foundations and methods of inquiry (pp. 233-263). San Francisco, CA: Berrett-Koehler Publishers, Inc.

Shank, G. D. (2002). Qualitative research: A personal skills approach. Upper Saddle River, NJ: Merrill Prentice Hall.

Short, J., Williams, E., \& Christie, B. (1976). The social psychology of telecommunications. London, UK: John Wiley \& Sons.

Smith, R. D. (2009). Virtual voices: Online teachers' perceptions of online teaching standards. Journal of Technology and Teacher Education, 17(4), 547-571.

Sparkes, R., \& Williams, L. (2000). Supporting learning: Ministerial panel on educational delivery in the classroom. St. John's, NL: Queen's Printing for Newfoundland and Labrador.

Stake, R. (1995). The art of case study research: Perspectives on practice. Thousand Oaks, CA: Sage Publications.

Surrey, D. W., \& Ely, D. P. (2007). Adoption, diffusion, implementation, and institutionalization of instructional innovations. In R. A. Reiser \& J. V. Dempsey (Eds.), Trends and issues in instructional design and technology (2nd ed., pp. 104-122). Upper Saddle River, NJ: Pearson Education, Inc.

Tu, C. H. (2002). The measurement of social presence in an online learning environment. International Journal on E-Learning, 1(2), 34-45.

Yin, R. K. (2003). Case study research: Design and methods (3rd ed.). Thousand Oaks, CA: Sage Publications. 